\title{
PHYSIOLOGICAL, AGRONOMICAL AND QUALITY RESPONSE OF BREAD WHEAT TO PHOSPHORUS APPLICATION UNDER DRYLAND CONDITION
}

\author{
KIZILGECI, F. \\ Department of Seed Production, Klzlltepe Vocational School, Mardin Artuklu University \\ 47400 Kizlltepe, Mardin, Turkey \\ e-mail:ferhat_kizilgeci@hotmail.com; phone:+90-532-501-0555
}

(Received $20^{\text {th }}$ Oct 2018; accepted $21^{\text {st }}$ Dec 2018)

\begin{abstract}
An understanding of physiological and agronomical traits associated with high grain yield and efficiency of phosphorus use is important to the improvement of genotypes under dryland conditions. An experiment was conducted to evaluate the influence of differentiated phosphorus fertilization rate on the yield and quality of wheat at the experimental farm, University of Dicle, Diyarbakir, Turkey during 20132014 and 2014-2015 growing seasons. The experiment was consisted of five treatments comprising of five phosphorus $\left(\mathrm{P}_{2} \mathrm{O}_{5}\right)$ levels $\left(0 \mathrm{~kg} \mathrm{ha}^{-1}, 30 \mathrm{~kg} \mathrm{ha}^{-1}, 60 \mathrm{~kg} \mathrm{ha}^{-1}, 90 \mathrm{~kg} \mathrm{ha}^{-1}\right.$ and $\left.120 \mathrm{~kg} \mathrm{ha}^{-1}\right)$. It was observed that phosphorus levels exhibited significant differences to the grain numbers per $\mathrm{m}^{2}$, grain weight and grain yield ha ${ }^{-1}$, as well as to starch content and protein content in the first season. There was no significant effect of phosphorus on all studied grain yield and quality characters in the second season. The improvement in grain yield was significantly associated with the increase in the values of grain number, accordingly, the coefficients of grain number and grain yield showed that grain number had a positive and direct effect on grain yield suggesting a criteria trait to enhance yield. It was concluded that the highest grain yield of wheat crop was obtained with $120 \mathrm{~kg} \mathrm{ha}^{-1} \mathrm{P}_{2} \mathrm{O}_{5}$ and it showed comparatively better performance than another treatment under investigation.
\end{abstract}

Keywords: wheat, grain yield and quality, protein yield, starch content, water use efficiency

\section{Introduction}

Wheat (Triticum aestivum L.) is one of the main essential food and a vital source of energy in human diet. It is one of the major significant and widely cultivated crop of the entire world and it is a major source of nourishment (Aktas, 2016; Kizilgeci et al., 2017; Khaled et al., 2018; Hossain et al., 2018). It is a principal food for more than $35 \%$ of the world's population, and a source of food and livelihood for over one billion people in developing countries (Metwali et al., 2011). Wheat grains used in the making of flour, breads, biscuits, cakes, cookies, pasta, noodles and also for beer, and other alcoholic beverages or biofuel. Presently, wheat is grown on more than 200 million hectares of the world's cultivated land and is the most important agricultural commodity in international trade (FAO, 2010). The worldwide requirements of wheat production by 2020 reached about 950 million tons to achieve food needs imposed by the increase of population and further, this could be reached, if global wheat productivity is enriched by 2.5\% yearly. (Singh et al., 2011; Barutcular et al., 2017; Yildirim et al., 2018). Consequently, to feed the rapidly growing population of the world, food production should be heightened.

Phosphorus is a necessary nutrient for the normal development of the plant (Kaleem et al., 2009). The quality and productivity of wheat crop may be affected by the management of primary fertilizers (NPK) but, it is also physiologically dependent on the different micronutrients along major nutrient management (Wiatrak et al., 2006). It plays an important role and has a number of functions in the growth of plant. It utilizes 
sugar and starch and involved in transfer of energy (Mumtaz et al., 2014). Balanced fertilization not only enhanced the yield of wheat, but also had a good influence on phosphorus uptake by plants (Rehman et al., 2006). While, deficiency of phosphorus is one of the factor of abiotic stresses that determine the productivity of cereal crops ( $\mathrm{Yu}$ et al., 2013). Deficiencies regarding soil phosphorus (P) and zinc ( $\mathrm{Zn}$ ) noticed widely in numerous regions across the globe (Marschner, 1995). Keeping in view the importance of phosphorus in crop productivity, the aim of the field study was to evaluate the response of bread wheat in terms of growth, yield and quality properties to different rates of phosphorus fertilization.

\section{Materials and methods}

\section{Plant material and growing conditions}

Two field experiments were conducted under rainfed conditions at the experimental farm, University of Dicle, Diyarbakir (latitude $37^{\circ} 88^{\prime} \mathrm{N}$, longitude $40^{\circ} 27^{\prime} \mathrm{E}$, altitude 680 m above sea level), Turkey (Figure 1).

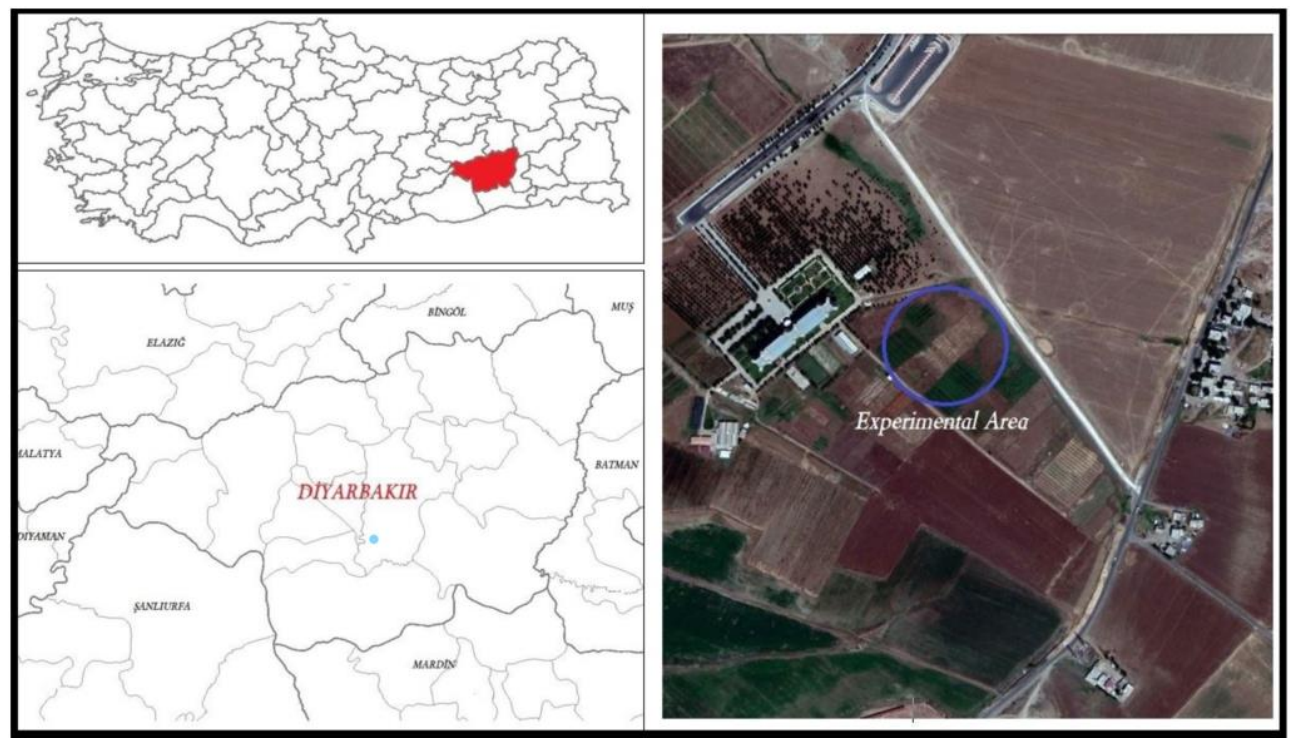

Figure 1. Map of the experimental area

Seeds of wheat cv: Pehlivan were sown on 12.12.2013 in the 1st year and on 26.12.2014 in the 2nd year. Pehlivan is one of the most important winter bread wheat variety registered in 1998. It has a medium early growth cycle. The spike is white, smooth, awnless and compact, and the plant height is $95-100 \mathrm{~cm}$. The variety has high productive tillering with high winter hardiness to be grown in winter wheat areas of the Central Anatolian Plateau with a medium tolerance to drought. Pehlivan also has medium opposition to lodging. It is suitable for growing on fertile and poor fertile soils, and is grown in most wheat producing regions of Turkey. The grain is oval, hard-red, very large, and has good milling and baking qualities.

The physical and chemical properties of the soil used in the experiment were as follows: clay soil (71.6\% clay), organic matter $1.25 \%$, available phosphoros $16.3 \mathrm{~kg}$ $\mathrm{ha}^{-1}$, salt $0.01 \%$, calcareous $13.02 \%, \mathrm{pH} 7.73$. Meteorological data were given in Table 
1. The experiment was arranged in randomized complete block design with four replications. The plots were arranged in six rows with $4 \mathrm{~m}$ long, $0.2 \mathrm{~m}$ intra-row using an experimental sowing machine. Five phosphorus $\left(\mathrm{P}_{2} \mathrm{O}_{5}\right)$ levels $(0,30,60,90$ and 120 $\mathrm{kg} \mathrm{P}_{2} \mathrm{O}_{5} \mathrm{ha}^{-1}$ ) were established in the form of triple super phosphate. The trial was conducted under rainfed conditions. Genotype were sown at a seed rate of 450 seed m-2. Nitrogen fertilization was carried out 2 times in the form of ammonium nitrate $(33 \% \mathrm{~N})$. $60 \mathrm{~kg} \mathrm{ha}^{-1}$ was applied at the sowing (basal dose) and tillering stage, in accordance with recommendations.

Table 1. Meteorological data of experimental area for the season 2013-2014 and 2014-2015

\begin{tabular}{c|c|c|c|c|c|c|c|c|c|c|c}
\hline Years & & Oct. & Nov. & Dec. & Jan. & Feb. & Mar. & Apr. & May & June & $\begin{array}{c}\text { Total/ } \\
\text { average }\end{array}$ \\
\hline 2013-2014 & Precipitation $(\mathrm{mm})$ & 0.0 & 53.8 & 50.4 & 43.0 & 17.0 & 60.6 & 39.9 & 48.8 & 21.4 & 334.9 \\
& Temperature $\left({ }^{\circ} \mathrm{C}\right)$ & 17.0 & 11.4 & -3.4 & 3.4 & 5.0 & 10.8 & 14.7 & 19.7 & 26.5 & 11.7 \\
\hline \begin{tabular}{c}
$2014-2015$ \\
\hline $\begin{array}{c}\text { Long- } \\
\text { term } \\
\text { 2015) }\end{array}$
\end{tabular} & Precipitation $(\mathrm{mm})$ & 84.2 & 10.4 & 31.6 & 77.4 & 69.2 & 55.6 & 29.0 & 41.4 & 18.4 & 417.2 \\
\hline
\end{tabular}

\section{Data collection and measurements}

The chlorophyll content (SPAD) at the midpoint of the flag leaves of 10 randomly selected plants in each plot was measured by using a portable chlorophyll meter (Minolta SPAD-502, Osaka, Japan). Grain yield $\left(\mathrm{kg} \mathrm{ha}^{-1}\right)$ was calculated in harvest plots. Grain yield in kilogram per hectare was calculated from the yield harvested from each plot, the plants collected with a harvester from the area were used for assessments of grain yield. The grain weight included a moisture content of $12 \%$. The sampling and determination of grain quality traits were described according to AACC (2000).

\section{Water use efficiency (WUE)}

Water-use efficiency is normally described as the ratio of crop yield to the amount of water needed to achieve the yield according to total consumed water through wheat life circle, WUE was measured by referring to Gao (2000) and Gao et al. (2004).

\section{Statistical analysis}

The obtained data were subjected to analysis of variance as described by Gomez and Gomez (1984). The data were statistically analyzed by using MSTAT-C package program. The Least Significant Differences (LSD) test was used to compare the treatments at 0.05 levels.

\section{Results and discussion}

The statistical analysis of variance (Table 2) illustrated the influence of phosphorus on the yield and quality traits of wheat. It is evident from the table that the number of 
grains per $\mathrm{m}^{2}$, thousand grain weight and grain yield were influenced significantly by the application of $\mathrm{P}$ fertilizer treatment in the first season. The analysis data showed that the analysis of variance of quality properties resulted in significant difference for phosphorus levels applications. Phosphorus fertilizer application also significantly infulenced the starch and protein content only in the 2014 growing season (Table 3). However, the maximum number of grains $\mathrm{m}^{-2}$ was observed with the application of 120 $\mathrm{kg} \mathrm{P}_{2} \mathrm{O}_{5} \mathrm{ha}^{-1}$. While, the minimum value for number of grains was observed in control treatment. The results are in agreement with the findings of Ravnskov et al. (1995) and Reuter et al. (1995) who found that the application of phosphatic fertilizer significantly enhanced the number of grains per hill or per $\mathrm{m}^{2}$ area.

Data regarding thousand grain weight influenced by various phosphorus rates are presented in (Table 2). Data after statistical analysis showed significant $(\mathrm{p} \leq 0.05)$ effect of various phosphorus rates on thousand grain weight. Data after statistical analysis revealed that in wheat crop thousand grain weight were significantly $(p \leq 0.05)$ affected by phosphorus levels and maximum weight of thousand grains was recorded from plots applied with $120 \mathrm{~kg} \mathrm{P}_{2} \mathrm{O}_{5} \mathrm{ha}^{-1}$, while the minimum thousand grain weight was observed from the control plot. Rahmatullah et al. (1994) found $90 \mathrm{~kg} \mathrm{P}_{2} \mathrm{O}_{5} \mathrm{ha}^{-1}$ the optimum rate for the greatest growth, development thousand grain weight of wheat. Similarly, Brennan (1992) found a progressive improvement in thousand grains weight with the increase in phosphorus dose from 60 to $120 \mathrm{~kg} \mathrm{P}_{2} \mathrm{O}_{5} \mathrm{ha}^{-1}$, gradually.

It was intensively observed that, the data after statistical analysis showed significant $(\mathrm{p} \leq 0.05)$ effect of different levels of phosphorus on grain yield. Mean values for different phosphorus levels revealed that maximum grain yield were produced by the plots that received $120 \mathrm{~kg} \mathrm{P}_{2} \mathrm{O}_{5} \mathrm{ha}^{-1}$, while less grain yield were produced by the control plots. The plot treated $120 \mathrm{~kg} \mathrm{P}_{2} \mathrm{O}_{5} \mathrm{ha}^{-1}$ achieved maximum yield $\left(4510 \mathrm{~kg} \mathrm{ha}^{-1}\right)$ which was statistically significant only in the first season, while the minimum grain yield $(3100 \mathrm{~kg}$ $\mathrm{ha}^{-1}$ ) was achieved in control plots in the first season. The main reason for the increase in grain yield with various rates of phosphatic fertilizer could be the higher thousand grain weight which might be due to higher rate of photosynthesis and better crop health which ultimately enhanced the final grain yield (Iqbal et al., 2003; Mehdi et al., 2003). Alam et al. (2003) has observed that the application of phosphorus fertilizer (SSP) to wheat has significantly improved the plant height, number of tillers plant ${ }^{-1}$, straw and grain yield as well as P-uptake in grain over control. Regardless of the second year crop, phosphorus fertilizers shown no significant effect on the grain yield and attributes. This results are in agreement with the findings of Mihoub and Deraoui (2014), who observed that phosphorus fertilizer application did not effect significantly the P content in grain yield. The relationship of high grain yield, due to $\mathrm{P}$ fertilizer application with number of seed/plant have been reported elsewhere (Singh et al., 2012).

The analysis results of Protein yield $\left(\mathrm{g} \mathrm{m}^{-2}\right)$ and Starch yield, $\left(\mathrm{g} \mathrm{m}^{-2}\right)$ of wheat are presented in (Table 3), results showed the effect of phosphorus levels, the statistical analysis of variance indicated that the mean Protein yield $\left(\mathrm{g} \mathrm{m}^{-2}\right)$ and Starch yield, $\left(\mathrm{g} \mathrm{m}^{-2}\right)$ were significantly different. Among various factors, plant nutrition circumstances usage of fertilizers, soil supply conditions - suit best to modify, and to enhance certain parameters (Sarkadi, 1981). According to views of several investigation variations in quality properties depend on fertilizing application (Tabl and Kiss, 1983). The yield traits and quality properties of wheat are usually affected by genotypes, environmental factors and their interactions (Barutcular et al., 2016). 
Table 2. Mean squares of the variance analysis for studied character

\begin{tabular}{|c|c|c|c|c|c|c|c|c|c|c|c|c|c|}
\hline Source of Variance & DF & SPAD & $\mathbf{P H}$ & GY & TGW & GN & PC & SC & WG & $\mathbf{Z S}$ & Hardness & PY & SY \\
\hline & & \multicolumn{12}{|c|}{2014} \\
\hline Block & 3 & 44.55 & 94.73 & 1331 & 1.91 & 670992.5 & 0.11 & 0.031 & 0.555 & 2.802 & 2.087 & 36.3 & 613.5 \\
\hline Phosphorus & 4 & 12.19 & 12.55 & $11163.825 * *$ & $2.234 *$ & $8666715.2 *$ & 0.26 & $0.104 *$ & 0.623 & 3.116 & 0.878 & $213.648 *$ & 4949.4 \\
\hline Error & 12 & 7.71 & 11.82 & 1878 & 0.42 & 1731320 & 0.15 & 0.028 & 0.229 & 1.771 & 3.284 & 45.5 & 792.4 \\
\hline $\mathrm{CV}, \%$ & & 5.53 & 3.67 & 11.66 & 2.03 & 11.29 & 2.52 & 0.25 & 1.59 & 2.66 & 1.53 & 11.77 & 11.59 \\
\hline & & \multicolumn{12}{|c|}{2015} \\
\hline Replication & 3 & 6.58 & 146.87 & 2355 & 5.41 & 2408949 & 0.39 & 0.170 & 2.337 & 27.829 & 5.753 & 38.2 & 1008.0 \\
\hline Phosphorus & 4 & 3.33 & 47.08 & 3107 & 1.80 & 2843499 & 0.30 & 0.054 & 0.569 & 9.157 & 3.488 & 92.7 & 1319.9 \\
\hline Error & 12 & 2.88 & 26.58 & 1139 & 2.27 & 1229514 & 0.27 & 0.075 & 1.041 & 13.623 & 3.702 & 38.4 & 496.1 \\
\hline $\mathrm{CV}, \%$ & & 3.62 & 5.60 & 7.98 & 4.02 & 9.78 & 3.65 & 0.43 & 3.46 & 7.64 & 1.84 & 10.29 & 8.19 \\
\hline
\end{tabular}

*, **, Significance level at 0.05 and 0.01 probability. DF: Degree of freedom.GY: Grain yield, PH: Plant height, TGW: Thousand grain weight, GN: Grain number $\mathrm{m}^{2}$, PC: Protein content, SC: Starch content ZS: Zeleny sedimantation, WG: Wet gluten, PY: Protein yield, SY:Starch yield

Table 3. Means of investigated traits in 2013-2014 and 2014-2015

\begin{tabular}{|c|c|c|c|c|c|c|c|c|c|c|c|c|}
\hline $\begin{array}{l}\text { Phosphorus } \\
\text { level }\end{array}$ & $\begin{array}{l}\text { SPAD } \\
\text { (unit) }\end{array}$ & $\begin{array}{l}\text { Plant } \\
\text { height } \\
\text { (cm) }\end{array}$ & $\begin{array}{c}\text { Grain } \\
\text { yield } \\
\left(\mathbf{k g ~ h a}^{-1}\right)\end{array}$ & $\begin{array}{c}\text { 1000- } \\
\text { Grain } \\
\text { weight }(\mathrm{g})\end{array}$ & $\begin{array}{c}\text { Grain } \\
\text { number } \\
\mathbf{m}^{2}\end{array}$ & $\begin{array}{l}\text { Protein } \\
\text { content } \\
(\%)\end{array}$ & $\begin{array}{c}\text { Starch } \\
\text { content } \\
(\%)\end{array}$ & $\begin{array}{c}\text { Wet } \\
\text { gluten } \\
(\%)\end{array}$ & $\begin{array}{c}\text { Zeleny } \\
\text { sedimentation } \\
(\mathbf{m l})\end{array}$ & Hardness & $\begin{array}{l}\text { Protein } \\
\text { yield } \\
\left(\mathrm{g} \mathrm{m}^{-2}\right)\end{array}$ & $\begin{array}{l}\text { Starch } \\
\text { yield } \\
\left(\mathrm{g} \mathrm{m}^{-2}\right)\end{array}$ \\
\hline & \multicolumn{12}{|c|}{2014} \\
\hline 0 & 48.6 & 92 & 3100 & 30.6 & 10124 & 15.9 & 65.3 & 30.7 & 51.5 & 118 & 49.2 & 202 \\
\hline 30 & 48.8 & 94 & 3400 & 32.2 & 10581 & 15.5 & 65.5 & 30.0 & 49.7 & 119 & 52.7 & 223 \\
\hline 60 & 53.0 & 95 & 3750 & 31.8 & 11800 & 15.5 & 65.6 & 30.2 & 49.6 & 119 & 57.3 & 243 \\
\hline 90 & 50.4 & 92 & 3830 & 32.3 & 11838 & 15.4 & 65.7 & 29.9 & 49.5 & 119 & 58.9 & 251 \\
\hline 120 & 50.1 & 96 & 4510 & 32.3 & 13917 & 15.2 & 65.7 & 29.7 & 49.5 & 118 & 68.4 & 296 \\
\hline Mean & 50.2 & 94 & 3720 & 31.8 & 11652 & 15.5 & 65.5 & 30.1 & 50.0 & 119 & 57.3 & 243 \\
\hline \multirow[t]{2}{*}{ LSD 0.05} & $\mathrm{Ns}$ & $\mathrm{ns}$ & 668 & 1.0 & 2027.0 & $\mathrm{~ns}$ & 0.15 & $\mathrm{~ns}$ & $\mathrm{~ns}$ & ns & 5.99 & 25.0 \\
\hline & \multicolumn{12}{|c|}{2015} \\
\hline 0 & 45.4 & 88.5 & 3860 & 37.3 & 10355 & 14.0 & 64.3 & 29.0 & 46.5 & 105 & 54.1 & 248 \\
\hline 30 & 46.6 & 89.0 & 4060 & 38.2 & 10622 & 13.9 & 64.2 & 29.4 & 46.8 & 103 & 56.4 & 261 \\
\hline 60 & 47.6 & 96.8 & 4380 & 36.4 & 12044 & 14.3 & 64.5 & 29.6 & 49.1 & 105 & 62.7 & 282 \\
\hline 90 & 47.2 & 92.5 & 4270 & 37.5 & 11403 & 14.6 & 64.2 & 30.0 & 49.9 & 106 & 62.2 & 274 \\
\hline 120 & 47.5 & 93.8 & 4580 & 37.7 & 12266 & 14.3 & 64.4 & 29.6 & 49.0 & 104 & 65.7 & 295 \\
\hline Mean & 46.9 & 92 & 4230 & 37.4 & 11338 & 14.2 & 64.3 & 29.5 & 48.3 & 105 & 60.2 & 272 \\
\hline LSD 0.05 & Ns & ns & $\mathrm{ns}$ & ns & ns & ns & $\mathrm{ns}$ & $\mathrm{ns}$ & $\mathrm{ns}$ & ns & $\mathrm{ns}$ & ns \\
\hline
\end{tabular}




\section{Correlation analysis}

Correlation coefficients between all traits are illustrated in Table 4 and grain yield of wheat crop show positive association with correlation coefficient values of grain number. Grain number was significant to high grain yield for both years. Under the low rainfall year (2014); Grain yield was positively and significantly influenced by 1000grain weight. The SPAD value was positively and significantly associated with the grain yield in the 2nd year of 2015, which was a year with high rainfall. The extent of association of different traits also revealed the significant relationship with grain yield of the crop and this result was supported by Shah et al. (2003). In general, it is believed that grain quality improved with the increament of phosphorus rates, and phosphorus caused remarkable improvement in protein yield. The protein content was negatively associated with grain yield. The unit increase in grain yield was positively associated with the increased values of observed crop parameters by various yield attributes, grains spike $^{-1}$, seed index and harvest index (Noonari et al., 2016).

Table 4. Correlation matrix of yield and quality traits under rainfed condition during the growing season since 2013-2014 and 2014-2015 in Diyarbakir

\begin{tabular}{|c|c|c|c|c|c|c|c|c|c|c|c|c|}
\hline Traits & GY & SPAD & $\mathrm{PH}$ & TGW & GN & $\mathrm{PC}$ & $\mathrm{SC}$ & WG & ZS & Hardness & PY & SY \\
\hline & \multicolumn{12}{|c|}{2014} \\
\hline GY & 1.000 & & & & & & & & & & & \\
\hline SPAD & 0.393 & 1.000 & & & & & & & & & & \\
\hline $\mathrm{PH}$ & 0.693 & 0.427 & 1.000 & & & & & & & & & \\
\hline TGW & 0.695 & 0.278 & 0.472 & 1.000 & & & & & & & & \\
\hline GN & $0.995^{* *}$ & 0.402 & 0.699 & 0.618 & 1.000 & & & & & & & \\
\hline $\mathrm{PC}$ & -0.918 & -0.351 & -0.658 & -0.922 & -0.872 & 1.000 & & & & & & \\
\hline SC & 0.867 & 0.531 & 0.468 & $0.884^{*}$ & 0.823 & -0.938 & 1.000 & & & & & \\
\hline WGC & -0.836 & -0.201 & -0.551 & -0.962 & -0.775 & $0.979^{* *}$ & -0.902 & 1.000 & & & & \\
\hline $\mathrm{ZS}$ & -0.707 & -0.518 & -0.556 & -0.964 & -0.639 & $0.907^{*}$ & -0.912 & $0.903^{*}$ & 1.000 & & & \\
\hline Hardness & -0.150 & 0.430 & -0.102 & 0.492 & -0.229 & -0.179 & 0.327 & -0.240 & -0.570 & 1.000 & & \\
\hline PY & $0.999^{* *}$ & 0.362 & 0.675 & 0.675 & $0.996^{* *}$ & -0.905 & 0.853 & -0.825 & -0.679 & -0.188 & 1.000 & \\
\hline \multirow[t]{2}{*}{ SY } & $0.999^{* *}$ & 0.363 & 0.683 & 0.704 & $0.992^{* *}$ & -0.922 & 0.866 & -0.847 & -0.706 & -0.156 & $0.999^{* *}$ & 1.000 \\
\hline & \multicolumn{12}{|c|}{2015} \\
\hline GY & 1.000 & & & & & & & & & & & \\
\hline SPAD & $0.923^{*}$ & 1.000 & & & & & & & & & & \\
\hline $\mathrm{PH}$ & 0.822 & 0.862 & 1.000 & & & & & & & & & \\
\hline TGW & -0.189 & -0.241 & -0.687 & 1.000 & & & & & & & & \\
\hline GN & $0.975^{* *}$ & $0.905^{*}$ & $0.917^{*}$ & -0.402 & 1.000 & & & & & & & \\
\hline $\mathrm{PC}$ & 0.616 & 0.642 & 0.639 & -0.343 & 0.642 & 1.000 & & & & & & \\
\hline $\mathrm{SC}$ & 0.535 & 0.432 & 0.765 & -0.760 & 0.680 & 0.124 & 1.000 & & & & & \\
\hline WGC & 0.670 & 0.810 & 0.587 & -0.054 & 0.620 & 0.863 & -0.063 & 1.000 & & & & \\
\hline ZS & 0.798 & 0.840 & 0.799 & -0.361 & 0.815 & $0.954^{*}$ & 0.284 & $0.911^{*}$ & 1.000 & & & \\
\hline Hardness & 0.024 & 0.053 & 0.314 & -0.584 & 0.148 & 0.743 & 0.067 & 0.386 & 0.553 & 1.000 & & \\
\hline PY & $0.985^{* *}$ & $0.918^{*}$ & 0.839 & -0.243 & $0.971^{* *}$ & 0.743 & 0.491 & 0.750 & $0.885^{*}$ & 0.189 & 1.000 & \\
\hline SY & $1.000^{* *}$ & $0.920^{*}$ & 0.823 & -0.193 & $0.976^{* *}$ & 0.603 & 0.547 & 0.657 & 0.788 & 0.012 & $0.982^{* *}$ & 1.000 \\
\hline
\end{tabular}

*, **, \%5 and \%1 significant, respectively, GY: Grain yield, PH: Plant height, TGW: Thousand grain weight, GN: Grain number $\mathrm{m}^{2}$, PC: Protein content, SC: Starch content ZS: Zeleny sedimantation, WG: Wet gluten, PY: Protein yield, SY:Starch yield 


\section{Water use efficiency}

Increasing phosphorus levels were positively and significantly improved water use efficiency (WUE) under low rainfall conditions (Figure 2). The WUE values are regulated, and the relationship is stronger. However, as reported by Gerloff (1977), when the performance of cultivars to P supply and their yield potential at low P supply. There are various considerations of $\mathrm{P}$ use efficiency in previous investigations of wheat, which have resulted in various definitions, such as agronomic efficiency (Alam et al., 2003).While, the non-significant inffluence of $P$ application on crop water use might be that $90 \mathrm{~kg} \mathrm{P} \mathrm{ha}{ }^{-1}$ was too high to influence root growth for superior water extraction (Lusiba et al., 2018). However, there is a deficiency of information on the interactive influence of phosphorus fertilizer on water use efficiency of wheat under dry conditions.

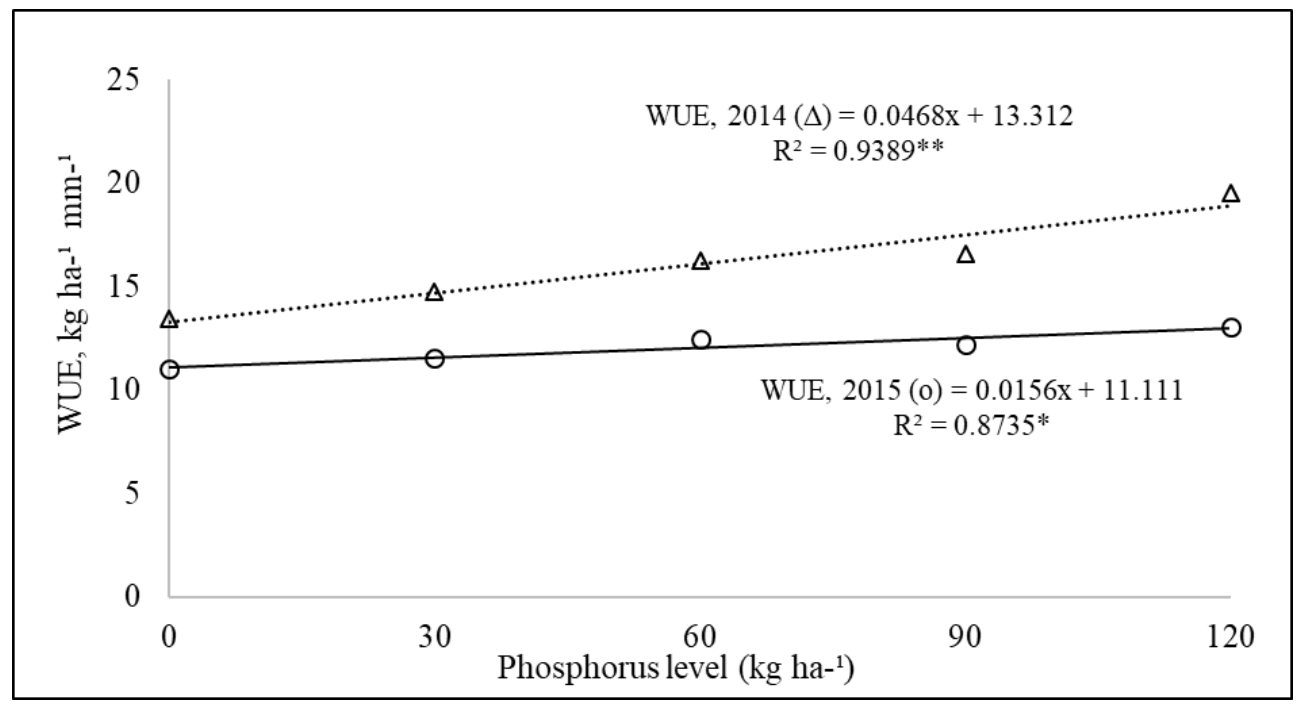

Figure 2. Relationship between water use efficiency (WUE) and phosphorus level

\section{Conclusion}

All these results indicate that phosphorus levels exhibited significant differences to the grain number per $\mathrm{m}^{2}$, grain weight and grain yield ha ${ }^{-1}$, as well as, for starch content and protein content in the first season. Evaluation of agronomical and quality traits in wheat showed that phosphurus application has significant effect on relationship between grain yield and quality. The grain yield increase was significantly associated with the improved values of noted plant traits like grain number and thousand grain weight. Accordingly, $120 \mathrm{~kg} \mathrm{P}_{2} \mathrm{O}_{5} \mathrm{ha}^{-1}$ was better rate of phosphorus for achieving reasonable productivity of wheat under investigation conditions.

\section{REFERENCES}

[1] AACC (2000): Approved methods of the American Association of Cereal Chemists. 10th Ed. American Association of Cereal Chemists, St. Paul, MN, USA.

[2] Aktas, H. (2016): Tracing highly adapted stable yielding bread wheat (Triticum aestivum L.) genotypes for greatly variable South-Eastern Turkey. - Applied Ecology and Environmental Research 14(4): 159-176. 
[3] Alam, S. M., Azam, S., Ali, S., Iqbal, M. (2003): Wheat yield and P fertilizer efficiency as influenced by rate and integrated use of chemical and organic fertilizers. - Pakistan Journal of Soil Science 22(2): 72-76.

[4] Barutcular, C., Yildirim, M., Koç, M., Akinci, C., Toptaş, I., Albayrak, O., Tanrıkulu, A., EL Sabagh, A. (2016): Evaluation of SPAD chlorophyll in spring wheat genotypes under different environments. - Fresenius Environmental Bulletin 25(4): 1258-1266.

[5] Barutcular, C., EL Sabagh, A., Koc, M., Ratnasekera, D. (2017): Relationships between grain yield and physiological traits of durum wheat varieties under drought and high temperature stress in Mediterranean environments. - Fresenius Environmental Bulletin 26(6): 4282-4291.

[6] Brennan, R. F. (1992): Effect of super phosphate and nitrogen on yield and take all of wheat. - Fertilizer Research 31(10): 43-49.

[7] FAO (2010): Food Agriculture Organization. - www.fao.org.

[8] Gao, J. F. (2000): Experimental Technology in Plant Physiology. - World Books Publishing Company, Xi'an, China.

[9] Gao, S. J., Wang, W. J., Guo, T. C. (2004): C-N metabolic characteristics in flag leaf and starch accumulating developments in seed during grain filling stage in two winter wheat cultivars with different spike type. - Acta Agronomica Sinica 29(3): 427-431.

[10] Gerloff, G. C. (1977): Plant efficiencies in the use of N, P and K. - In: Wright, M. J. (ed.) Plant adaptation to mineral stress in problem soils. Cornell University Press, New York: 161-174.

[11] Gomez, K. A., Gomez, A. A. (1984): Statistical Procedures for Agricultural Research. 2nd Ed. Johwiley and Sons, Inc. New York.

[12] Hossain, M. M., Hossain, A., Alam, M. A., EL Sabagh, A., Ibn Murad, K. F., Haque, M. M., Muriruzzaman, M., Islam, M. Z., Das, S. (2018): Evaluation of Fifty Spring Wheat Genotypes Grown Under Heat Stress Condition In Multiple Environments Of Bangladesh. - Fresenius Environmental Bulletin 27(9): 5993-6004.

[13] Iqbal, Z., Latif, A., Ali, S., Iqbal, M. M. (2003): Effect of fertgated phosphorus on P use efficiency and yield of wheat and maize. - Songklanakarin Journal Science Technology 25: 697-702.

[14] Kaleem, S., Ansar, M., Ali, M. A., Sher, A., Ahmad, G., Rashid, M. (2009): Effect of phoshorus on the yield and yield components of wheat variety "Inquilab-91" under rainfed conditions. - Sarhad Journal Agriculture 25(1): 21-24.

[15] Khaled, A. A., Reda, O. I., Hafez, M. Y., Esmail, S. M., EL Sabagh, A. (2018): Anatomical, biochemical and physiological changes in some Egyptian wheat cultivars inoculated with Puccinia gramini f. sp. tritici f. sp. tritici f.sp. tritici. - Fresenius Environmental Bulletin 27(1): 296-305.

[16] Kizilgeci, F., Tazebay, N., Namli, M., Ozturk, O., Yildirim M. (2017): The drought effect on seed germination and seedling growth in bread wheat (Triticum Aestivum L.). International Journal of Agriculture, Environment and Food Sciences 1(1): 33-37.

[17] Lusiba, S., Odhiambo, J., Ogola, J. (2018): Growth, yield and water use efficiency of chickpea (Cicer arietinum): response to biochar and phosphorus fertilizer application. Archives of Agronomy and Soil Science 64(6): 819-833.

[18] Marschner, H. (1995): Mineral Nutrition of Higher Plants. - 2nd Ed. Academic press, London UK, pp: 229-312.

[19] Mehdi, S. M., Sajjad, N., Sarfraz, M., Hassan, B. Y. K. G. (2003): Response of wheat to different phosphatic fertilizer in varying textured salt affected soils. - Pakistan Journal of Applied Sciences 3: 474-480.

[20] Mihoub, A., Deraoui, B. N. (2014): Performance of different phosphorus fertilizer types on wheat grown in calcareous sandy soil of El-menia, southern Algeria. - Asian Journal of Crop Science 6: 383-391. 
[21] Mumtaz, M. Z., Aslam, M., Jamil, M., Ahmad, M. (2014): Effect of different phosphorus levels on growth and yield of wheat under water stress conditions. - Journal of Environment and Earth Science 4(19): 23-30.

[22] Noonari, S., Kalhoro, S. A., Ali, A., Mahar, A., Raza, S., Ahmed, M., Shah, S. F. A., Baloch, S. U. (2016): Effect of Different Levels of Phosphorus and Method of Application on the Growth and Yield of Wheat. - Natural Science 8: 305-314.

[23] Rahmatullah, M. A., Gill, M. A., Sheikh, B. Z., Zia, M. S. (1994): Inorganic phosphorus fractions and their availability for plant uptake in several calcareous soils. - In: Proc 4th national cong Soil Sci May 24-26, Islamabad Pakistan.

[24] Ravnskov, S., Jakobsen, I. (1995): Functional compatibility in arbuscular mycorrhizas measured as hypal P transport to the plant. - New Phytol 129: 611-618.

[25] Rehman, O., Zaka, M. A., Rafa, H. U., Hassan, N. M. (2006): Effect of balanced fertilization on yield and phosphorus uptake in what-rice rotation. - J. Agric. Res. 44(2): 105-113.

[26] Reuter, J., Dyson, C. B., Elliott, E. D., Lewis, D. C., Rudd, C. L. (1995): An appraisal of soil phosphorus testing data for crops and pastures in South Australia. - Australian Journal of Experimental Agriculture 35: 979-995.

[27] Sarkadi, J. (1981): Főbb szántóföldi növényeink tápanyag felvételi dinamikája és fajlagos tápanyagigénye. - In: Debreczeni, B. A. (ed.) Növények ásványi táplálkozása és a mütrágyázása. Gödöllő, 169-184. In Hungarian.

[28] Shah, K. H., Siddiqui, S. H., Memon, M. Y., Aslam, M., Imliaz, M., Khan, P. (2003): Performance of FertigationTechnique for P Usage Efficiency in Wheat. - Asian Journal of Plant Sciences 2: 1088-1091.

[29] Singh, K., Sharma, S. N., Sharma, Y. (2011): Effect of high temperature on yield attributing traits in bread wheat. - Bangladesh Journal of Agricultural Research 36(3): 415-426.

[30] Singh, G., Sekhon, H. S., Kaur, H. (2012): Effect of farmyard manure, vermicomposting and chemical nutrients on growth and yield of chickpea (Cicer arietinum L.). International J Agric Res. 7: 93-99.

[31] Tabl, M. M., Kiss, A. (1983): Effects of nitrogen fertilisation and plant density on amino acid composition of hexaploids of Triticale and wheat. - Archiv fuer Zuechtungsforschung 13(4): 95-101.

[32] Wiatrak, P. J., Wright, D. L., Marois, J. J. (2006): The impact of tillage and residual nitrogen on wheat. - Soil and Tillage Research 91(1): 150-156.

[33] Yildirim, M., Barutcular, C., Hossain, A., Koç, M., Dizlek, H., Akinci, C., Toptaş, I., Basdemir, F., Islam, M. S., EL Sabagh, A. (2018): Assessment of The Grain Quality of Wheat Genotypes Grown Under Multiple Environments Using GGE Biplot Analysis. Fresenius Environmental Bulletin 27(7): 4830-4837.

[34] Yu, W., Chi, S. Y., Ning, T. Y., Tian, S. Z., Li, Z. J. (2013): Coupling Effects of Irrigation and Phosphorus Fertilizer Applications on Phosphorus Uptake and Use Efficiency of Winter Wheat. - Journal of Integrative Agriculture 12(2): 263-272. 